\title{
GMR
}

\section{Pharmacology of a traditional Chinese herb, Shuangren-Anshen capsule, in a hemorrhage mouse model by using an orthogonal array design}

\author{
X.X. Liu ${ }^{1 *}$, A. Agudamu2*, X. Zhang ${ }^{2}$, Y. Wei ${ }^{1}$, X. Song ${ }^{3}$ and Y.L. Li ${ }^{1}$ \\ ${ }^{1}$ School of Pharmaceutical Science, Shanxi Medical University, \\ Taiyuan, China \\ ${ }^{2}$ School of Production and Utilization of Food Science, \\ Rakuno Gakuen University, Hokkaido, Japan \\ ${ }^{3}$ The Second Hospital of Shanxi Medical University, Taiyuan, China \\ *These authors contributed equally to this study. \\ Corresponding author: Y.L. Li \\ E-mail: liyunlanrr@163.com
}

Genet. Mol. Res. 15 (3): gmr.15038806

Received May 16, 2016

Accepted June 3, 2016

Published July 25, 2016

DOI http://dx.doi.org/10.4238/gmr.15038806

Copyright (C) 2016 The Authors. This is an open-access article distributed under the terms of the Creative Commons Attribution ShareAlike (CC BY-SA) 4.0 License.

\begin{abstract}
Shuangren-Anshen capsule (SAC) is a traditional Chinese herb that was improved in our laboratory. An orthogonal experiment $\left[\mathrm{L}_{9}(3)^{4}\right]$ was used to optimize the extraction conditions. In vivo, a hemorrhage mouse model was established and the hemoglobin contents of normal control, model control, and treated mice were measured. Additionally, the sedative and hypnotic effects of SACs were assessed based on pharmacological parameters such as changes in locomotive activity, forelimb raising, sleep latency, sleep duration, and number of mice that fell asleep. Brain tissue was sectioned and stained to detect
\end{abstract}


changes in cell morphology by microscopy. The optimum extraction was achieved with 3 cycles of decoction for 120 min each with a 10-fold volume of water added. In the model control group, hemoglobin content significantly decreased and pharmacological parameters increased ( $\mathrm{P}$ $<0.01)$ relative to that in the normal control group. Compared to the model control group, the group treated with $0.9 \mathrm{~g} / \mathrm{kg}$ SAC showed significant $(\mathrm{P}<0.05)$ increase or decrease in hemoglobin content and all pharmacological parameters except sleep duration. The groups treated with 1.8 or $3.6 \mathrm{~g} / \mathrm{kg} \mathrm{SAC}$ and the positive control group also showed significant alterations in hemoglobin content and pharmacological parameters $(\mathrm{P}<0.05)$. In addition, $\mathrm{SAC}$ exhibited a protective effect on the morphological structures of the damaged nerve cells in the mouse model. Thus, an optimal extraction process was successfully identified. The pharmacological data also suggests that the drug can improve sleep quality. SAC treatment was shown to cause changes in hemoglobin content and cell morphology in a mouse model.

Key words: Hemorrhage mouse model; Nerve cell morphology; Orthogonal array design; Pharmacology; Shuangren-Anshen capsule

\section{INTRODUCTION}

Sleep deprivation is a common disorder that is often attributed to the accelerated pace of modern social life and work pressures. Sleep deprivation can have significant adverse effects on mental health and may exacerbate many physical disorders. It has been suggested that naturally derived treatments may have comparable efficacy and fewer side effects than synthetic drugs (Zhang, 2004).

Sleep-wake disturbances have not been widely examined, but a recent study suggested that hemorrhage contributes to insomnia (Schuiling et al., 2005), ischemic stroke can result in sleep-wake disturbances and sleep-related movement disorder (Hermann and Bassetti, 2009), and the correlation between post-stroke sleep-wake disturbances and sleep electroencephalography is poor in patients with brain damage (Bassetti et al., 1996; Hermann et al., 2008). These results suggest that hemorrhage causes hemoglobin levels to decrease (He and Wang, 2008), insomnia, and damage to nerve cells. However, other studies have shown that moderate exercise benefits individuals with sleep disorders, improving blood circulation and reducing anxiety-related symptoms (Zielinski et al., 2013). Moderate exercise was also reported to have sedative and hypnotic effects on locomotive activity and on the latency, duration, and rate of sleep in mice (Huang et al., 2007; Wu et al., 2011). Traditional Chinese medicine suggests a link between blood-related disorders and insomnia. Particularly, blood deficiencies are thought to weaken the spleen and stomach and decrease cardiac blood supply, thereby causing heart palpitations and insomnia. Exercise has been shown to effectively reduce anxiety and improve cognitive metrics in human patients (Cotman and Berchtold, 2002; Strohle, 2009), and recent studies indicated that exercise can attenuate anxiety-related sleep deprivation in rodents (Vollert et al., 2011).

In this study, a hemorrhagic mouse model (Qi, 2002) was established in which changes in hemoglobin content were measured, pharmacological parameters of insomnia

Genetics and Molecular Research 15 (3): gmr.15038806 
induced by hemorrhage (such as behavior and synergistic effect on sleep with pentobarbital) were assessed, and changes in the morphology of nerve cells caused by hemorrhage were determined. Particularly, the sedative activity of a traditional Chinese medicine, ShuangrenAnshen capsule (SAC), was evaluated for its ability to modulate blood hemoglobin levels, cause changes in anxiety-related behavior, and repair damaged nerve cells in hemorrhagic mice to investigate the potential clinical use of SAC for treating hemorrhage-induced insomnia. The bioactive compound geniposide was used as a quality control marker to monitor the raw herbal materials in SAC. Geniposide is a water-soluble bioactive ingredient derived from the dried ripe fruits of Gardenia jasminoides Ellis (Rubiaceae). The neurotrophic properties of geniposide have been well-characterized and is the compound is known to be a selective agonist of the glucagon-like peptide-1 receptor (Liu et al., 2009). Genipin, a metabolite of geniposide, reportedly polymerizes hemoglobin as a blood substitute (Chang et al., 2004). The chemical structure of genipin is shown in Figure 1. Geniposide is found in a wide variety of traditional medicinal plants with various properties, including sedative (Zhaolin et al., 2009), antiphlogistic, and diuretic effects (Harada et al., 1974). In addition, geniposide is an important bioactive element of SAC.

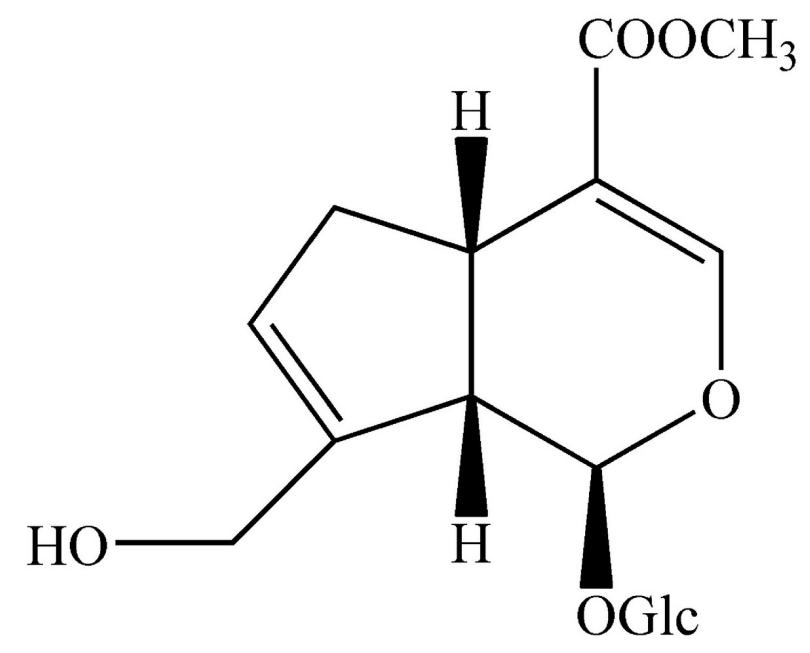

Figure 1. Chemical structure of geniposide from Gardenia jasminoides Ellis [1,4 $\alpha, 5,7 \alpha$-tetrahydro-1-( $\beta$-Dglucopyranosyloxy)-7-(hydroxymethyl)-cyclopenta(c)pyran-4-carboxylic acid methyl ester].

\section{MATERIAL AND METHODS}

\section{Instrumentation and reagents}

We used an HPLC machine (model 1200; Agilent Technologies, Santa Clara, CA, USA); an automatic instrument to measure the spontaneous activity of mice (ZIL-2; Institute of Materia Medica Chinese Academy of Medical Sciences); acrylic plastic boxes (30 x $20 \mathrm{x}$ $15 \mathrm{~cm}$ ) to observe forelimb raising of the mice; and an ultraviolet spectrophotometer (UV-721; ShangHai Optical Instrument Factory, Shanghai, China) to determine hemoglobin content in mice; optical microscope (OPTEC BDS200-PH; Chongqing Optec Instrument Co., Ltd., Chongqing, China) to observe the morphology of nerve cells. 
Sodium pentobarbital (Serve, Shanghai Chemical Reagent Corporation, Shanghai, China) was dissolved in $0.9 \% \mathrm{NaCl}$ solution to 25 or $45 \mathrm{mg} / \mathrm{kg}$ solution before use for intraperitoneal (i.p.) injection. SAC was dissolved in distilled water for intragastric (i.g.) administration. Liquid standards of cyanide methemoglobin (Zhongshan Research Institute of Tianjin, Tianjin, China) were used to create a standard curve with a spectrophotometer. Wenqishi solution (Zhongshan Research Institute of Tianjin, China) was used to dilute the mouse blood in order to measure the hemoglobin content using the cyanidation method (Song and Liu, 1991).

\section{Experimental animals}

Sixty Wistar mice (30 male, 30 female), weighing $20 \pm 2 \mathrm{~g}$, were purchased from the Experimental Animal Centre of Shanxi University (license number: SCXK D01-01007). We performed completely randomized grouping of mice into six groups $(\mathrm{N}=10$ in each group: 5 male and 5 female): 1) normal control, 2) model control, 3) positive control, 4) low-dose $(0.9 \mathrm{mg} / \mathrm{kg}) \mathrm{SAC}, 5)$ medium-dose (1.8 mg $/ \mathrm{kg}) \mathrm{SAC}$, and 6) high-dose $(3.6 \mathrm{mg} / \mathrm{kg}) \mathrm{SAC}$. The normal and model control groups were given $0.9 \% \mathrm{NaCl}$ solution (i.g.). The positive control group received Shuian capsule (SHC) and the other three groups received SAC; all drugs were dissolved in distilled water were given by i.g. administration $(0.2 \mathrm{~mL} / 10 \mathrm{~g}$, volume/body weight) for 5 consecutive days.

All experiments followed a protocol approved by the local animal ethics committee and the local government.

\section{Preparation of medicinal extracts}

The raw herbal materials consisted of $20 \mathrm{~g}$ untreated and $10 \mathrm{~g}$ fried Semen Zizyphi Spinosae (Zizyphus jujuba seed), $10 \mathrm{~g}$ tuckahoe (Wolfiporia extensa), 12 g Gardenia jasminoides Ellis, $7 \mathrm{~g}$ Chinese angelica (Angelica sinensis), $10 \mathrm{~g}$ tuber fleeceflower stem, $10 \mathrm{~g}$ bupleurum (Bupleurum chinense), $10 \mathrm{~g}$ turmeric (Curcuma longa) root tuber, $10 \mathrm{~g}$ dwarf lilyturf (Ophiopogon japonicus) tuber, $7 \mathrm{~g}$ white peony (Paeonia obovata var. alba) root, 3 g Radix Glycyrrhizae Preparata (baked licorice (Glycyrrhiza glabra) root), and $3 \mathrm{~g}$ grassleaf sweetflag (Acorus gramineus) rhizome, which were all botanically authenticated. These materials were combined and then decocted with distilled boiling water and filtered. The combined extract was concentrated to one-tenth the original volume and then dried under a vacuum at $60^{\circ} \mathrm{C}$. The dry extract was ground to powder using a pulverizer and sieved through a $250-\mu \mathrm{m}$ filter.

\section{Orthogonal assay}

An orthogonal assay design (OAD) with a three-factor interaction (volume of water, duration of extraction, and duration of decoction) was used. The OAD is an analytical chemistry method introduced in 1989 by Oles and Yankovich, and has been used not only to improve production reliability and estimate the best conditions for extraction efficiency, but also to enhance the properties of the target product, in this case, the dry extract rate and yield of geniposide.

Genetics and Molecular Research 15 (3): gmr.15038806 


\section{Establishment of hemorrhage mouse model and determination of hemoglobin content}

We investigated whether SAC can improve the pathological symptoms in this mouse model. The left eyeball of each mouse was removed, causing blood loss of approximately $0.5 \mathrm{~mL}$, which was collected in microcentrifuge tubes. The eye socket was then packed with cotton to stop the bleeding to induce the acute hemorrhagic model.

Absorbance values (A) were measured using 4 concentrations of cyanide methemoglobin as liquid standards $(50,100,150,200 \mathrm{~g} \mathrm{Hb} / \mathrm{L}$ ) in a spectrometer (UV-721) to obtain a standard curve. Blood was collected from each mouse by cutting approximately $1-2 \mathrm{~cm}$ from the tail and squeezing the blood onto a glass slide. Blood $(20 \mu \mathrm{L})$ was then removed into a test tube containing $5 \mathrm{~mL}$ Wenqishi solution, which was the thinner of hemiglobincyanide. The blood/Wenqishi mixture was then diluted at 1:2 with distilled water and the mixture shaken until the blood was completely dispersed. The cyanmethemoglobin method was used to examine hemoglobin content. The tube was then incubated for $5 \mathrm{~min}$ to ensure that the reaction $\left(\mathrm{Fe}^{3+}\right.$ and cyanide) was complete. Next, methemoglobin in the mixture was detected by spectrophotometry at $540 \mathrm{~nm}$ at $60 \mathrm{~min}$ after the last administration. The hemoglobin concentration in each group of mice was calculated using the standard curve.

\section{Pharmacological test}

\section{Locomotor activity}

Sedative activity was examined by determining the locomotor activity of the mice over a 10-min period using the YLS-1A Multi-autonomous Activity Instrument. The relevant treatment was administered i.g. to the 6 groups $60 \mathrm{~min}$ before the test.

\section{Pentobarbital-induced sleep in mice}

Mice in different groups (10 for each group) received i.g. administration of physiological saline or SAC $60 \mathrm{~min}$ before the experiment. We used $45 \mathrm{mg} / \mathrm{kg}$ (i.p.) pentobarbital as the hypnotic dosage and $25 \mathrm{mg} / \mathrm{kg}$ (i.p.) as the sub-hypnotic dosage. The elapsed time between pentobarbital injection and loss of righting reflex for each mouse was regarded as the sleep latency and the time between loss of righting reflex and recovery was regarded as the sleep duration. In the sub-pentobarbital test, the mouse loss of righting reflex over 1 min was considered to indicate a sleeping state after pentobarbital injection within $30 \mathrm{~min}$.

\section{Morphological observation of nerve cells}

The mice were sacrificed by dislocation. The brain was carefully removed onto the surface of a cold dish $\left(0^{\circ} \mathrm{C}\right)$, the blood was washed out with distilled water, and the tissue placed immediately in $4 \%$ paraformaldehyde solution and fixed for $2 \mathrm{~h}$. The sections were dehydrated through a graded alcohol series $(75,85,95 \%$ twice, and 100\% 3 times), cleared in xylene, and embedded in paraffin wax. Brain tissue was cut into $5-\mu \mathrm{m}$-thick slices on a microtome mounted onto a clean glass slide and incubated for $4 \mathrm{~h}$ at $60^{\circ} \mathrm{C}$. Sections were stained with hematoxylin for $10 \mathrm{~min}$, differentiated with hydrochloric acid alcohol, rinsed with tap water, and stained with eosin for $1 \mathrm{~min}$. Next, the sections were dehydrated in a gradient 
alcohol series, cleared with xylene, and sealed with neutral resin. The slides were placed under a microscope to assess the pathological morphological changes in the brain tissue.

\section{Statistical analysis}

The OAD results were analyzed by analysis of variance. The pharmacodynamics data are shown in Figure 1. The significance of differences between groups was assessed using the Student's $t$-test. For the sedative dose of pentobarbital, the $\chi^{2}$ test was used to compare the number of mice that fell asleep in the pentobarbital-treated group compared with each of the other groups. Statistical significance was set at $\mathrm{P}<0.05$.

\section{RESULTS}

\section{Analysis of orthogonal design}

The OAD was used to optimize the extraction of raw herbal materials for SACs. Extraction of geniposide from $G$. jasminoides Ellis by decoction depends on the 3 variables (volume of water, duration of extraction, and duration of decoction), which are shown in Table 1. To evaluate the effects of these variables, the mean values of the total score for these 3 factors at each level were calculated according to the assignment of the experiment. The major findings are shown in Tables 2 and 3 . The mean value, $R$, of the different variables at different levels revealed varying extraction efficiencies (Table 2). Analysis of variance further indicated the OAD results. As shown in Table 3, the duration of decoction statistically significantly (at least $\mathrm{P}<0.05$ ) contributed to geniposide extraction. Based on the findings of OAD analysis, the optimal combination of extraction conditions for geniposide was a 10fold volume of water added to the herbs and 3 cycles of decoction, with extraction duration of $120 \mathrm{~min}$ for each decoction. Thus, we determined the optimal combination of extraction conditions.

Table 1. Factors and levels of the orthogonal array design $\mathrm{L}_{9}\left(3^{4}\right)$ matrix.

\begin{tabular}{l|c|c|c}
\hline \multirow{2}{*}{ Levels } & \multicolumn{3}{|c}{ Factors } \\
\cline { 2 - 4 } & A(Volume of water) & B [Extraction time (h)] & C (Times of decoction) \\
\hline 1 & 8-fold & 1 & 1 \\
\hline 2 & 10-fold & 2 & 2 \\
\hline 3 & 12-fold & 3 & 3 \\
\hline
\end{tabular}

\section{Interaction between SAC ingredients}

To determine the content of geniposide in SAC, a standard addition approach (HPLC) was used. The results are shown in Figure 2. The retention times for geniposide of SAC and standard solution showed no difference. Additionally, spectrometry peaks for geniposide were not observed in the geniposide blank capsule. This finding indicates that geniposide was distinctly separated by HPLC from the other components in SAC and negative control without interference. Thus, an HPLC method was established to quantify geniposide.

Genetics and Molecular Research 15 (3): gmr.15038806 
Table 2. Orthogonal array design matrix $\mathrm{L}_{9}\left(3^{4}\right)$ and experimental results.

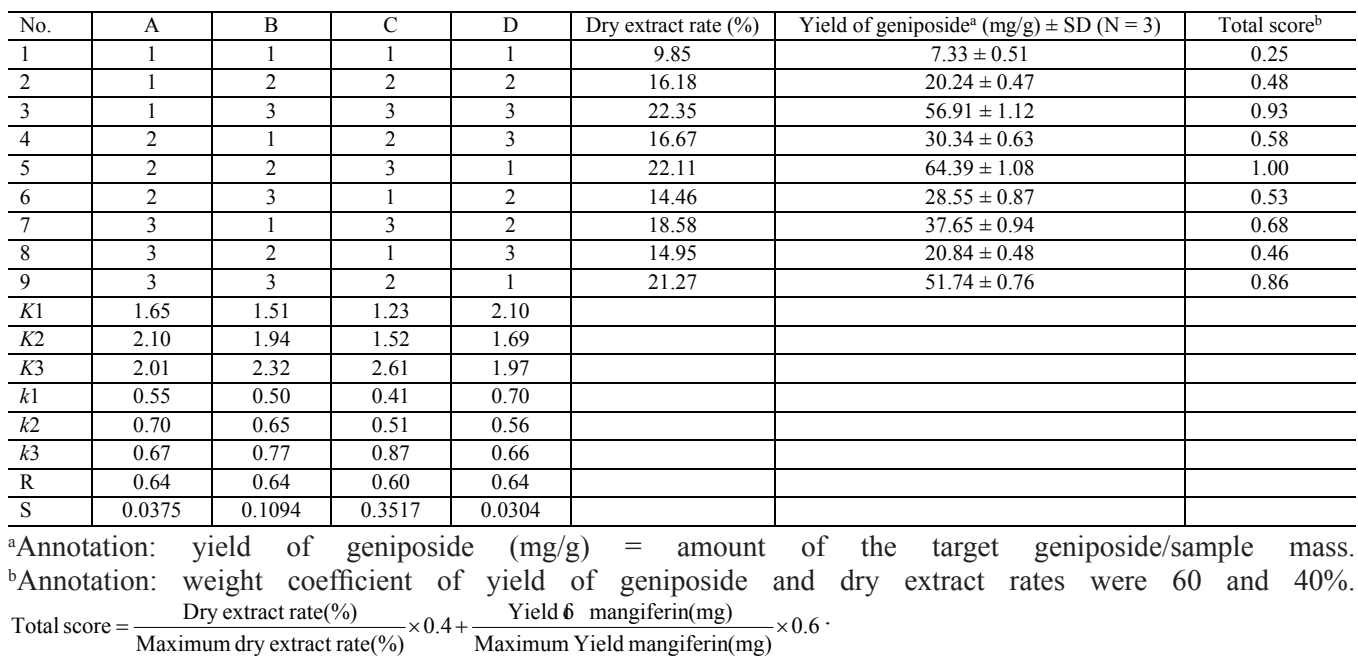

Table 3. Analysis of variance of experimental factors.

\begin{tabular}{l|c|c|c|c|c}
\hline Source & Sum of squares & d.f. & Variance & $F^{\text {a }}$ & Significance \\
\hline Volume of water & 0.0375 & 2 & 0.019 & 1.3 & \\
\hline Extraction time $(\mathrm{h})$ & 0.1094 & 2 & 0.055 & 3.7 & \\
\hline Times of decoction & 0.3517 & 2 & 0.176 & 11.7 & $\mathrm{P}<0.05$ \\
\hline Pooled error & 0.0304 & 2 & 0.015 & &
\end{tabular}

annotation: $F_{0.10}(2,2)=9 ; F_{0.05}(2,2)=19 ; F_{0.01}(2,2)=99$, P: level of significance.

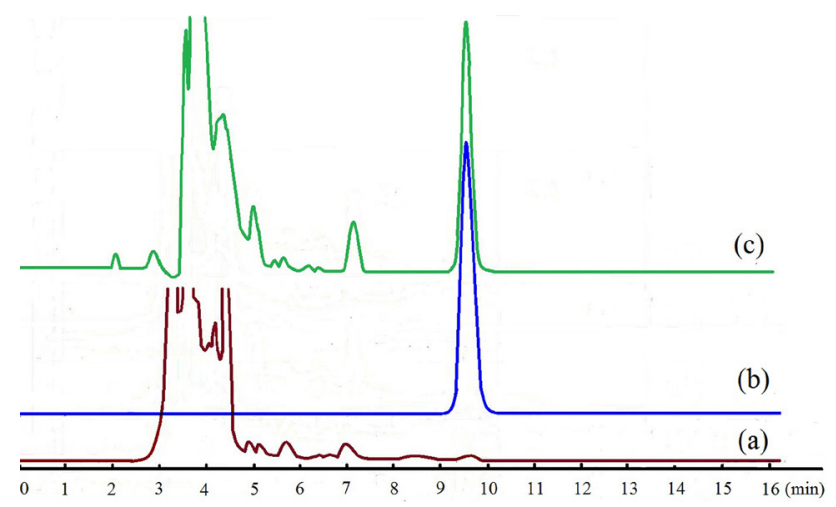

Figure 2. Represent chromatograms of geniposide (a) blank capsule (except for Gardenia jasminoides Ellis); (b) standard solutions of geniposide $(49.8 \mu \mathrm{g} / \mathrm{mL})$; (c) Shuangren-Anshen capsule (including Gardenia jasminoides Ellis).

\section{Effect of SAC on hemoglobin content in mice}

Hemoglobin content was determined using the cyanmethemoglobin method to determine whether the mouse model of hemorrhage-related insomnia was successfully established (Table 4). There was a significant difference $(\mathrm{P}<0.01)$ between the model and 
normal control groups, and the hemoglobin content of blood in the anemic mice improved after SAC treatment $(\mathrm{P}<0.05)$. These results indicate that the blood supply was increased and that SAC shows blood supply and sedative effects. Thus, a change in hemoglobin indicated not only that the mouse model was a successful model of hemorrhage-related insomnia, but also indicated the efficacy of SAC treatment in the model.

Table 4. Effect of SAC on change in hemoglobin content.

\begin{tabular}{l|c|c}
\hline Groups & Dose $(\mathrm{mg} / \mathrm{kg})$ & Hemoglobin content $(\mathrm{M})$ \\
\hline Normal & - & $150.7 \pm 9.1$ \\
\hline Model & - & $119.4 \pm 14.1^{\mathrm{a} * *}$ \\
\hline SHC & 1.5 & $137.2 \pm 13.8^{\mathrm{a} *, \mathrm{~b} *}$ \\
\hline SAC & 0.9 & $140.2 \pm 8.3^{\mathrm{a} *, \mathrm{~b} * *}$ \\
\hline SAC & 1.8 & $144.8 \pm 7.3^{\mathrm{b} *}$ \\
\hline SAC & 3.6 & $137.8 \pm 8.2^{\mathrm{a} * *, \mathrm{~b} * *}$ \\
\hline
\end{tabular}

Values are reported as means $\pm \mathrm{SEM}, \mathrm{N}=10$ mice. $\mathrm{SAC}=$ Shuangren-Anshen capsule; $\mathrm{SHC}=$ Shuian capsule. ${ }^{\mathrm{a} C}$ Compared to normal. ${ }^{\mathrm{b}}$ Compared to model. $* \mathrm{P}<0.05$, $* * \mathrm{P}<0.01$.

\section{Pharmacological test}

Pharmacological parameters such as changes in locomotive activity, sleep latency, sleep duration, and number of mice that fell asleep were examined to evaluate the pharmacological effects of SAC. The findings of this experiment show that hemoglobin content, locomotive activity, sleep duration, and sleep rate were reduced and sleep latency was increased before treatment relative to in normal control mice, but these parameters improved significantly after treatment with SAC and SHC. Common complaints of long sleepers with poor sleep quality include difficulty falling asleep, awakening too early, and awakening during the night (Tsai et al., 2014). SAC helped the mouse models to fall asleep quickly and wake up less often, indicating improved sleep quality.

\section{Effect of SAC on locomotor activity of mice}

The locomotor activity of mice was detected (Table 5). The locomotor activity of the anemia mouse model was significantly decreased compared to in the normal control group $(\mathrm{P}<0.01)$. Five days after treatment, the locomotor activity of all $3 \mathrm{SAC}$ (low, medium, and high) groups and the SHC group was significantly $(\mathrm{P}<0.05)$ improved compared to the model control group. The effect was similar to the normal group under the same conditions, but remained lower than the control group in all 4 treated groups.

Table 5. Effect of SAC on locomotion activity in mice.
\begin{tabular}{l|c|c}
\hline Groups & Dose $(\mathrm{mg} / \mathrm{kg})$ & Times on locomotion activity \\
\hline Normal & - & $541.9 \pm 36.2$ \\
\hline Model & - & $458.0 \pm 37.1^{\mathrm{a} * *}$ \\
\hline SHC & 1.5 & $500.9 \pm 24.4^{\mathrm{b*}}$ \\
\hline SAC & 0.9 & $489.3 \pm 39.6^{\mathrm{a} * *, b *}$ \\
\hline SAC & 1.8 & $520.6 \pm 25.1^{\mathrm{b} * *}$ \\
\hline SAC & 3.6 & $492.9 \pm 32.2^{\mathrm{a} * *, b *}$ \\
\hline
\end{tabular}

Values are reported as means $\pm \mathrm{SEM}, \mathrm{N}=10$ mice. $\mathrm{SAC}=$ Shuangren-Anshen capsule; $\mathrm{SHC}=$ Shuian capsule. ${ }^{\mathrm{a}}$ Compared to normal. ${ }^{\mathrm{b}}$ Compared to model. $* \mathrm{P}<0.05$, $* * \mathrm{P}<0.01$.

Genetics and Molecular Research 15 (3): gmr.15038806 


\section{Effect of SAC on the sleeping onset of mice induced by hypnotic dosage of pentobarbital}

The sedative action of SAC determined in the sleep test, with sleep latency and duration induced by sodium pentobarbital $(45 \mathrm{mg} / \mathrm{kg})$, is shown in Table 6 . In contrast to the normal control group, sleep latency increased and sleep duration decreased significantly ( $\mathrm{P}$ $<0.01)$. SAC (all 3 doses) and SHC significantly reduced sleep latency $(\mathrm{P}<0.05)$ compared with the model control group. Additionally, SAC (at doses of 1.8 and $3.6 \mathrm{mg} / \mathrm{kg}$ ) and SHC significantly $(\mathrm{P}<0.05)$ prolonged sleep duration.

Table 6. Effect of SAC on the sleeping onset of mice.
\begin{tabular}{l|c|c|c}
\hline Groups & Dose $(\mathrm{mg} / \mathrm{kg})$ & Sleep latency $(\mathrm{s})$ & Sleeping time $(\mathrm{min})$ \\
\hline Normal & - & $135.9 \pm 15.3$ & $160.8 \pm 44.8$ \\
\hline Model & - & $160.4 \pm 20.5^{\mathrm{a} * *}$ & $105.4 \pm 22.3^{\mathrm{a} * *}$ \\
\hline SHC & 1.5 & $140.8 \pm 21.3^{\mathrm{b*}}$ & $143.8 \pm 56.9^{\mathrm{b} *}$ \\
\hline SAC & 0.9 & $139.8 \pm 18.1^{\mathrm{b*}}$ & $149.7 \pm 67.4$ \\
\hline SAC & 1.8 & $143.8 \pm 23.2^{\mathrm{b**}}$ & $153.4 \pm 62.4^{\mathrm{b*}}$ \\
\hline SAC & 3.6 & $138.3 \pm 16.3^{\mathrm{b*}}$ & $138.0 \pm 44.7^{\mathrm{b} *}$ \\
\hline
\end{tabular}

Values are reported as means $\pm \mathrm{SEM}, \mathrm{N}=10$ mice. SAC $=$ Shuangren-Anshen capsule; $\mathrm{SHC}=\mathrm{Shuian}$ capsule. ${ }^{\mathrm{a}}$ Compared to normal. ${ }^{\mathrm{b}} \mathrm{Compared}$ to model. ${ }^{*} \mathrm{P}<0.05, * * \mathrm{P}<0.01$.

\section{Effect of SAC on the number of sleeping mice induced by sedative dosage of pentobarbital}

As shown in Table 7, the number of mice falling asleep after the sedative dosage ( 25 $\mathrm{mg} / \mathrm{kg}$ ) of sodium pentobarbital was significantly higher in the SHC-treated and 3 SAC-treated groups compared with the normal control group $(\mathrm{P}<0.01)$ and model control group $(\mathrm{P}<0.05)$.

Table 7. Effect of SAC on the number of mice that fell asleep.
\begin{tabular}{l|c|c|c}
\hline Groups & Dose $(\mathrm{mg} / \mathrm{kg})$ & Number of sleeping mice & Sleeping rate $(\%)$ \\
\hline Normal & - & 0 & 0 \\
\hline Model & - & 1 & 10 \\
\hline SHC & 1.5 & 4 & $60^{\mathrm{a} * * \mathrm{~b} *}$ \\
\hline SAC & 0.9 & 6 & $40^{\mathrm{a} * \mathrm{~b} *}$ \\
\hline SAC & 1.8 & 4 & $60^{\mathrm{a} * *, \mathrm{~b} *}$ \\
\hline SAC & 3.6 & 7 & $70^{\mathrm{a} * *, \mathrm{~b} * *}$ \\
\hline
\end{tabular}

Values are reported as means $\pm \mathrm{SEM}, \mathrm{N}=10$ mice. $\mathrm{SAC}=$ Shuangren-Anshen capsule; $\mathrm{SHC}=\mathrm{Shuian}$ capsule. ${ }^{\mathrm{a}}$ Compared to normal. ${ }^{\mathrm{b}}$ Compared to model. ${ }^{*} \mathrm{P}<0.05, * * \mathrm{P}<0.01$.

\section{Effect of SAC on pathological study of brain tissue in mice}

The hematoxylin and eosin-stained sections revealed changes in the morphological structure of neurons in the mouse model (Figure 3). Delamination of the brain cell layer (external granular layer, pyramidal layer, and ganglion cell layer) was obvious in normal control mice (Figure 3A), but disappeared in model control mice (Figure 3B) and significantly improved after SAC administration (Figure 3C). In the external granular layer, the neural cell structure was normal and clear in the normal group (Figure $3 \mathrm{~A}_{1}$ ), but severe nuclear pycnosis was observed in the treated groups (Figure $3 \mathrm{~B}_{1}$ ), which was significantly alleviated after 
administration of SAC (Figure $3 \mathrm{C}_{1}$ ). All types of pyramidal cells were present in the pyramidal layer in the normal control group (Figure $3 \mathrm{~A}_{2}$ ), but the nerve cells were mostly hyperchromatic with karyopyknosis in the model control group (Figure $3 \mathrm{~B}_{2}$ ) and were similar to the normal value after administration of SAC (Figure $3 \mathrm{C}_{2}$ ). Large pyramidal cells, dendrites, and axons were clearly observed in the ganglion cell layer of normal control mice (Figure $3 \mathrm{~A}_{3}$ ), but were not distinct in model control mice (Figure $3 \mathrm{~B}_{3}$ ) and were clearly similar to the normal control mice after administration of SAC (Figure $3 \mathrm{C}_{3}$ ). Based on these findings, SAC treatment had a significant protective effect on damaged nerve cells and showed a sedative effect. Thus, the nerve cell morphology in SAC-treated mice was observed.
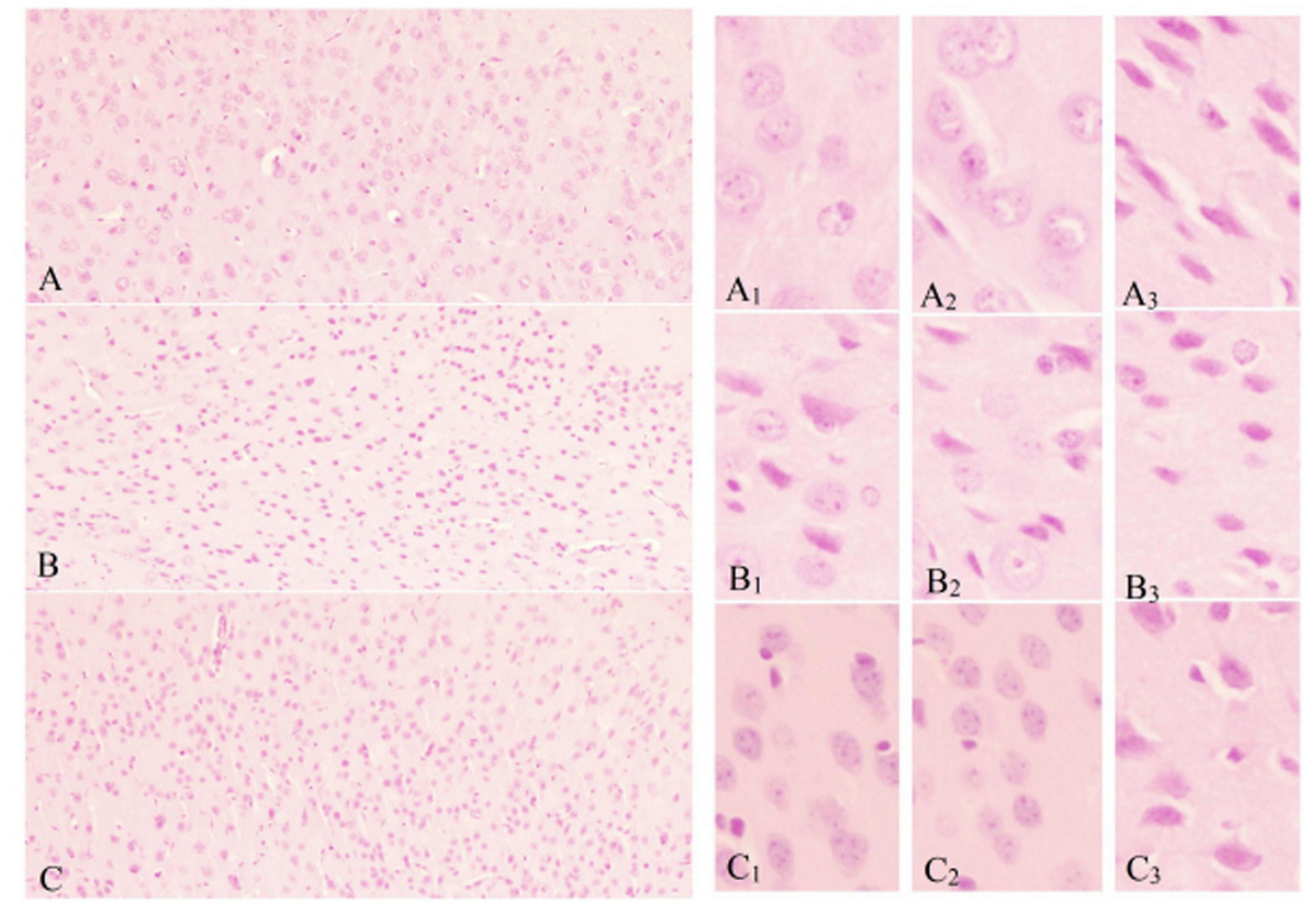

Figure 3. Delamination of brain cell in anemia model mice following treatment with normal saline (B) and SAC (C) and in normal control mice given normal saline without anemia (A) are shown (20X). Cellular morphology of external granular layer in the mouse brain was observed in the normal control group $\left(A_{1} x 40\right)$, model control group $\left(B_{1} \times 40\right)$, and SAC group $\left(C_{1} \times 40\right)$, the pyramidal layer in the normal control group $\left(A_{2} \times 40\right)$, model control group $\left(B_{2} \times 40\right)$, and SAC group $\left(C_{2} \times 40\right)$, and the ganglion cell layer was in normal the control group $\left(A_{3} \times 40\right)$, model control group ( $\left.\mathrm{B}_{3} \times 40\right)$, and SAC group $\left(\mathrm{C}_{3} \times 40\right)$. The brain cells were stained with hematoxylin and eosin and observed under a microscope.

\section{DISCUSSION}

In the present study, an orthogonal array design L9 $\left(3^{4}\right)$ was used to optimize the experimental conditions to improve the geniposide yield and dry extract rate to prepare SAC. The resulting method significantly improved the cost and extraction efficiency of the raw herbal materials, as well decreased the labor, preparation time, and environmental impact.

Genetics and Molecular Research 15 (3): gmr.15038806 
Additionally, the hematinic and sedative properties of SAC in a mouse model of hemorrhageinduced insomnia were characterized. The results indicated that SAC provides a significant therapeutic benefit, comparable to that afforded by an established drug (SHC). Mechanistically, the formulation appears to improve blood circulation to the brain, which helps in the repair of damaged nerve cells. Our data indicate that this SAC formulation is promising for the treatment of brain hemorrhage-related insomnia.

\section{Conflicts of interest}

The authors declare that they have no conflict of interests.

\section{ACKNOWLEDGMENTS}

Research supported by the Program for the Natural Science Foundation of Shanxi Province (\#2014011027-1), the Program for Science and Technology of Shanxi Province (\#201303130219), the Top Science and Technology Innovation Teams of Higher Learning Institutions of Shanxi Province, the Program for the Top Young and Middle-aged Innovative Talents of Higher Learning Institutions of Shanxi Province (2015), the Foundation of Young Academic Leader in Shanxi Province, and the Shanxi Province Returnees Preferred Project in 2012, Education Reform and Research Project of the Colleges and Universities of Shanxi Province.

\section{REFERENCES}

Bassetti C, Mathis J, Gugger M, Lovblad KO, et al. (1996). Hypersomnia following paramedian thalamic stroke: a report of 12 patients. Ann. Neurol. 39: 471-480. http://dx.doi.org/10.1002/ana.410390409

Chang WH, Chang Y, Chen YC and Sung HW (2004). Hemoglobin polymerized with a naturally occurring crosslinking agent as a blood substitute: in vitro and in vivo studies. Artif. Cells Blood Substit. Immobil. Biotechnol. 32: $243-262$. http://dx.doi.org/10.1081/BIO-120037830

Cotman CW and Berchtold NC (2002). Exercise: a behavioral intervention to enhance brain health and plasticity. Trends Neurosci. 25: 295-301. http://dx.doi.org/10.1016/S0166-2236(02)02143-4

Harada M, Tenmyo N, Aburada M and Endo T (1974). Phagmacological studies of gardeniae fructus. I. Effect of geniposide and genipin on the biliary excretion, the gastric juice secretion, and the gastric contraction, and other pharmacological actions (author's trans1). Yakugaku Zasshi 94: 157-162.

He XY and Wang GH (2008). Effect of Ginseng blood on hemorrhagic anemia mice. Lishizhen Med. Mat. Med. Res. 09: 02.

Hermann DM and Bassetti CL (2009). Sleep-related breathing and sleep-wake disturbances in ischemic stroke. Neurology 73: 1313-1322. http://dx.doi.org/10.1212/WNL.0b013e3181bd137c

Hermann DM, Siccoli M, Brugger P, Wachter K, et al. (2008). Evolution of neurological, neuropsychological and sleep-wake disturbances after paramedian thalamic stroke. Stroke 39: 62-68. http://dx.doi.org/10.1161/ STROKEAHA.107.494955

Huang F, Xiong Y, Xu L, Ma S, et al. (2007). Sedative and hypnotic activities of the ethanol fraction from Fructus Schisandrae in mice and rats. J. Ethnopharmacol. 110: 471-475. http://dx.doi.org/10.1016/j.jep.2006.10.008

Liu JH, Yin F, Guo LX, Deng XH, et al. (2009). Neuroprotection of geniposide against hydrogen peroxide induced PC12 cells injury: involvement of PI3 kinase signal pathway. Acta Pharmacol. Sin. 30: 159-165. http://dx.doi.org/10.1038/aps.2008.25

Qi C (2002). Research on the method of traditional Chinese medicine pharmacology. 2nd edn. People's Medical Publishing House, Beijing.

Schuiling WJ, Rinkel GJ, Walchenbach R and de Weerd AW (2005). Disorders of sleep and wake in patients after subarachnoid hemorrhage. Stroke 36: 578-582. http://dx.doi.org/10.1161/01.STR.0000154862.33213.73

Song SJ and Liu YJ (1991). Clinicians manual-inspection fascicle. Science and Technology Press of Shanghai, Shanghai.

Ströhle A (2009). Physical activity, exercise, depression and anxiety disorders. J. Neural. Transm. 116: 777-784. http:// dx.doi.org/10.1007/s00702-008-0092-x

Genetics and Molecular Research 15 (3): gmr.15038806 
Tsai TC, Wu JS, Yang YC, Huang YH, et al. (2014). Long sleep duration associated with a higher risk of increased arterial stiffness in males. Sleep 37: 1315-1320.

Vollert C, Zagaar M, Hovatta I, Taneja M, et al. (2011). Exercise prevents sleep deprivation-associated anxiety-like behavior in rats: potential role of oxidative stress mechanisms. Behav. Brain Res. 224: 233-240. http://dx.doi. org/10.1016/j.bbr.2011.05.010

Wu XY, Zhao JL, Zhang M, Li F, et al. (2011). Sedative, hypnotic and anticonvulsant activities of the ethanol fraction from Rhizoma Pinelliae Praeparatum. J. Ethnopharmacol. 135: 325-329. http://dx.doi.org/10.1016/j.jep.2011.03.016

Zhang ZJ (2004). Therapeutic effects of herbal extracts and constituents in animal models of psychiatric disorders. Life Sci. 75: 1659-1699. http://dx.doi.org/10.1016/j.lfs.2004.04.014

Zhaolin H, Lu J, Huilian C, Baoxia S, et al. (2009). Evaluation of sedative effects of geniposide and gardenia yellow extracted from cape jasmine fruit on mice. J. Food Sci. 15: 048.

Zielinski MR, Davis JM, Fadel JR and Youngstedt SD (2013). Influence of chronic moderate sleep restriction and exercise training on anxiety, spatial memory, and associated neurobiological measures in mice. Behav. Brain Res. 250: 74-80. http://dx.doi.org/10.1016/j.bbr.2013.04.038

Genetics and Molecular Research 15 (3): gmr.15038806 